\title{
Endoscopic Management of Acute Bleeding from an Ectopic Duodenal Varix
}

\author{
Maria Ana Túlio Susana Marques Miguel Bispo Tiago Bana Cristina Chagas \\ Gastroenterology Department, Hospital de Egas Moniz, Centro Hospitalar de Lisboa Ocidental, Lisbon, Portugal
}

\section{Keywords}

Duodenum - Gastrointestinal hemorrhage · Endoscopic hemostasis · Varicose veins

\section{Terapêutica Endoscópica de Hemorragia Aguda de uma Variz Ectópica Duodenal}

\section{Palavras Chave}

Duodeno $\cdot$ Hemorragia gastrointestinal $\cdot$ Hemostase endoscópica · Varizes

A 56-year-old male patient with chronic hepatitis C infection, without regular medical follow-up, was admitted due to severe acute gastrointestinal bleeding, manifested by syncope and melena. On examination, the patient was tachycardic (122 bpm), blood pressure was $96 / 65 \mathrm{~mm} \mathrm{Hg}$, and there were no evident stigmata of chronic liver disease. Empirical intravenous therapy with octreotide and esomeprazole was started.

At admission, hemoglobin level was $12.5 \mathrm{~g} / \mathrm{dL}$, with a subsequent $4 \mathrm{~g} / \mathrm{dL}$ drop in the first $6 \mathrm{~h}$. Remaining laboratory results showed INR 1.7 , platelets $61,000 / \mu \mathrm{L}$, bilirubin $2.2 \mathrm{mg} / \mathrm{dL}$, and serum aminotransferase levels about 2 times the upper limit of normal.

\section{KARGER}

E-Mail karger@karger.com www.karger.com/pjg (c) 2016 Sociedade Portuguesa de Gastrenterologia Published by S. Karger AG, Basel Karger Open access

This article is licensed under the Creative Commons AttributionNonCommercial-NoDerivatives 4.0 International License (CC BYNC-ND) (http://www.karger.com/Services/OpenAccessLicense) Usage and distribution for commercial purposes as well as any distribution of modified material requires written permission.
Urgent upper gastrointestinal endoscopy was performed and documented a small esophageal varix without evidence of recent bleeding and, in the inferior wall of the second portion of the duodenum, a 20 -mm elevated longitudinal lesion with a central hematinic depression, at that time misinterpreted as a subepithelial lesion with a visible vessel, and therefore, an endoclip was placed (Fig. 1).

Further investigation with endoscopic ultrasound (EUS) showed that the previously identified duodenal subepithelial lesion was in fact a 13-mm-large duodenal ectopic varix (Fig. 2a). Endoscopic injection of $4.8 \mathrm{~mL}$ of cyanoacrylate and lipiodol (0.5:0.7) was successfully per-

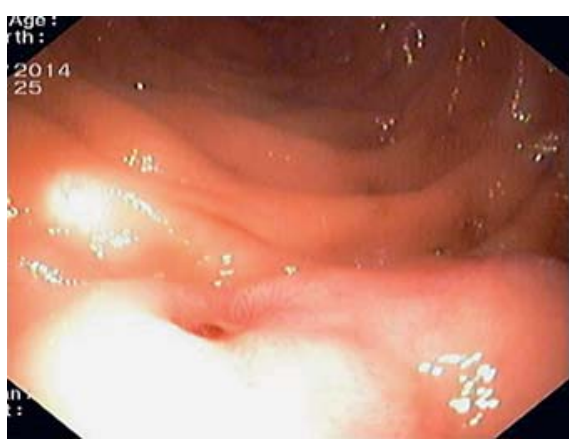

Fig. 1. Upper endoscopy showing a 20-mm subepithelial lesion (ectopic varix), with a central hematinic depression, in the second portion of the duodenum.

Dr. Maria Ana Túlio

Gastroenterology Department, Hospital de Egas Moniz

Centro Hospitalar de Lisboa Ocidental

PT-1349-019 Lisbon (Portugal)

E-Mail mariaanatulio@yahoo.com 
Fig. 2. Radial endoscopic ultrasound (duodenum): 13-mm duodenal varix, with blood flow on Doppler imaging (a). Onemonth follow-up EUS showing total obliteration of the variceal lumen in Doppler evaluation (b).

Fig. 3. Endoscopic image of duodenal varix 2 weeks after cyanoacrylate and lipiodol injection. Late extravasation of glue with mucosal ulceration and complete eradication of the ectopic varix was documented.
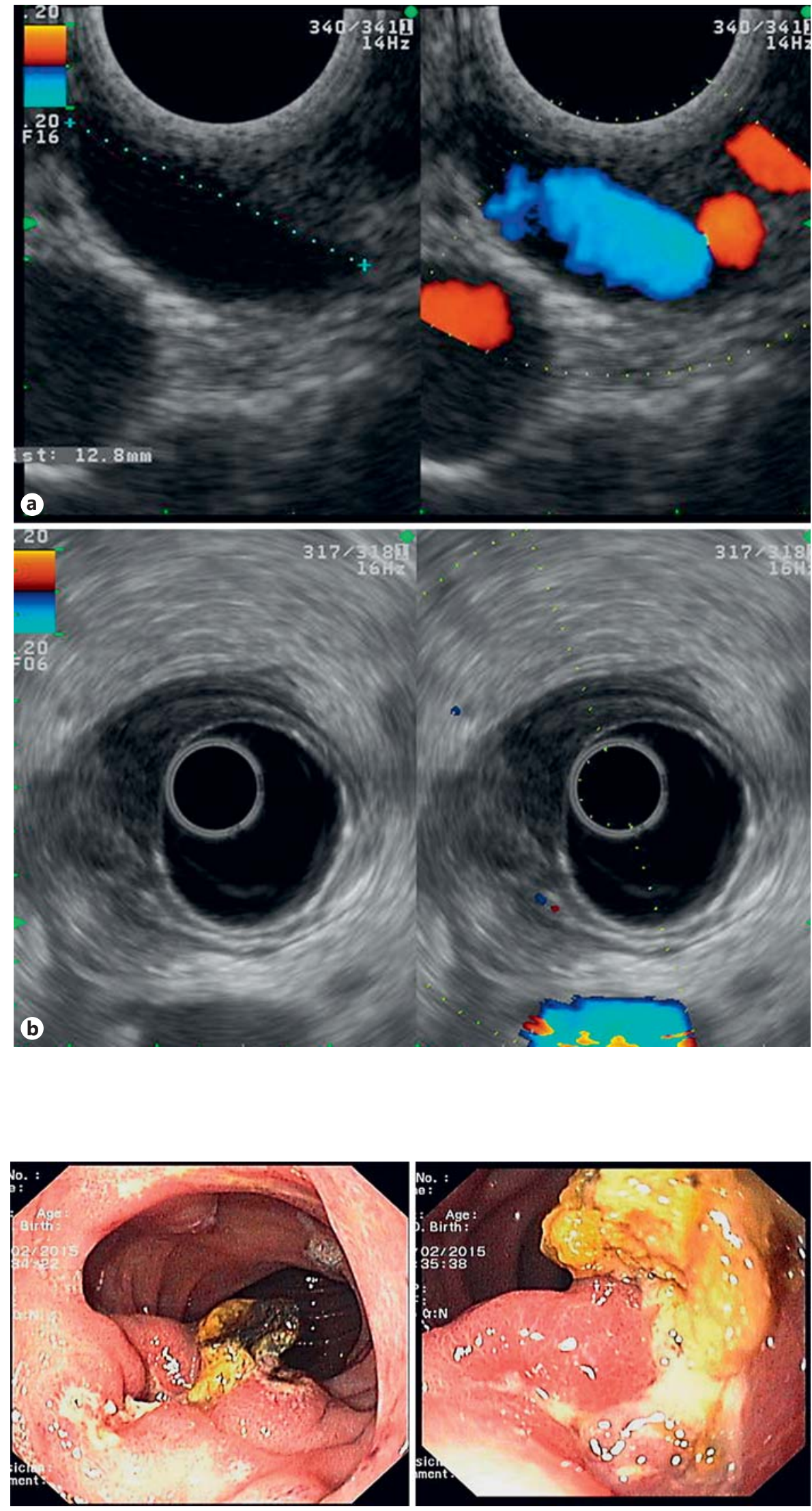

GE Port J Gastroenterol 2017;24:98-100 
formed. Endoscopic evaluation, 2 weeks postinjection documented ulceration and late extravasation of glue, with eradication of the ectopic varix (Fig. 3). EUS at 1 month of follow-up confirmed total obliteration of the variceal lumen (Fig. 2b). At 2 years of follow-up, the patient remains stable, with compensated cirrhosis following HCV eradication.

Gastrointestinal ectopic varices are dilated portosystemic collateral veins located out of the esophagus and stomach. They account for $1-5 \%$ of all variceal bleeding episodes and are associated with massive bleeding with high mortality rates ( $40 \%)$ [1]. The rupture of duodenal varices corresponds to $17 \%$ of all cases of rupture of ectopic varices, with the bulb being the most common site [2].

Although an endoscopic therapeutic approach is not yet consensually defined, there are some reports on the use of band ligation, injection sclerotherapy, and EUSguided angiotherapy (coil and/or cyanoacrylate injection). Although endoscopic band ligation can be used for temporary hemostasis, re-bleeding is frequent $[1,2]$. The use of endoscopic injection sclerotherapy with cyanoacrylate has been reported in some cases of bleeding due to duodenal varices, with favorable results. However, this technique may be associated with some adverse events, namely embolism and hemorrhage from postinjection ulcers [1-3]. EUS-guided angiotherapy (EUS-guided cyanoacrylate or coil therapy) is a recent technique, better described for the treatment of gastric varices, showing a similar variceal obliteration rate in fewer sessions and also fewer adverse events compared with the standard cyanoacrylate injection [4]. Recently, a case of duodenal varix bleeding successfully treated by EUS-guided therapy was reported [5].

In this rare case report, the inaugural presentation of cirrhosis was severe bleeding from an ectopic duodenal varix, which was successfully managed by endoscopic cyanoacrylate injection. As in the present case, EUS may play an important role in the definitive diagnosis of the underlying ectopic varix and in the evaluation of the permeability of the varix following therapy. Real-time EUSguided therapy may also be potentially useful in accessible ectopic varices, requiring further validation.

\section{Statement of Ethics}

The authors declare that no experiments were performed on humans or animals for this study, that they have followed the protocols of their work center on the publication of patient data, and that no patient data appear in this article.

\section{Disclosure Statement}

The authors have no conflicts of interest, financial or other, to declare.
References
1 Helmy A, Al Kahtani K, Al Fadda M: Updates in the pathogenesis, diagnosis and management of ectopic varices. Hepatol Int 2008;2: 322-334.

2 Sato T, Akaike J, Toyota J, Karino Y, Ohmura $\mathrm{T}$ : Clinicopathological features and treatment of ectopic varices with portal hypertension. Int J Hepatol 2011;2011:960720.

3 Rana SS, Bhasin DK, Sharma V, Chaudhary V, Sharma R, Singh K: Clinical, Endoscopic and endoscopic ultrasound features of duodenal varices: a report of 10 cases. Endosc Ultrasound 2014;3:54-57.
4 Romero-Castro R, Ellrichmann M, OrtizMoyano C, Subtil-Inigo JC, Junquera-Florez F, Gornals JB, et al: EUS-guided coil versus cyanoacrylate therapy for the treatment of gastric varices: a multicenter study (with videos). Gastrointest Endosc 2013;78:711-721.

5 Kinzel J, Pichetshote N, Dreadar S, Asianian $\mathrm{H}$, Nagar A: Bleeding from a duodenal varix: a unique case of variceal hemostasis achieved using EUS-guided placement of an embolization coil and cyanoacrylate. J Clin Gastroenterol 2014;48:362-364. 